\title{
A representação da homossexualidade nos discursos jurídicos sobre adoção homoparental
}

\author{
Rafael Morello Fernandes ${ }^{1}$ \\ Universidade Federal Rural do Rio de Janeiro, Seropédica, Rio de Janeiro, Brasil
}

DOI: 10.11606/issn.2316-9133.v22i22p250-261

resumo $\mathrm{O}$ artigo, fruto da minha pesquisa de mestrado, trata das representaçóes da homossexualidade a partir dos discursos jurídicos sobre adoção nas varas da infância, da juventude e do idoso da comarca da capital do Rio de janeiro. ${ }^{2}$ De acordo com os resultados preliminares da pesquisa, destaco duas estratégias na forma de lidar com a polêmica relação entre homossexualidade e parentalidade por parte dos envolvidos nos processos de adoção: a invisibilização das peculiaridades da adoçáo por casais homossexuais, como se a simples positivação da questão pelo judiciário resolvesse os conflitos que cercam a questão e certa "idealização" da homossexualidade, como se esta por si só representasse uma espécie de vantagem em termos de amadurecimento pessoal do candidato à adoção.

palavras-chave Família; Adoção; Homoparentalidade; Funçôes Parentais; Estigma

The representation of homossexuality in legal speeches about homoparental adoption

abstract The article, a result of my master's research, is about the homosexuality's representations from the legal speech's on adoption of children in the Child and Youth Courts of Rio de Janeiro. According to the preliminary results of the research, highlight two strategies in dealing with the controversial relation between homosexuality and parenthood by those involved in adoption processes: the invisibilization of the peculiarities of adoption by homosexual couples, like if the simple positivation of the question by the judiciary resolve the conflicts surrounding the issue, and also certain idealization of the homosexuality, as if it alone represented a kind of advantage in terms of maturation of the candidate for adoption.

keywords Family; Adoption; Homosexual adoption; Parental functions; Stigma

\section{Introdução}

Assiste-se no Brasil, assim como em outros países ocidentais, uma intensa mobilização social em torno da questão da homossexualidade. Reportagens, políticas públicas, trabalhos acadêmicos, personagens em tramas televisivas, projetos de lei de combate à violência contra homossexuais e transexuais e outros de "cura" destes, atestam a enorme atualidade das questóes relacionadas ao tema, formando um panorama complexo e multifacetado.

Um dos marcos recentes da garantia de direitos aos homossexuais no país foi a decisão do Supremo Tribunal Federal (2011) que reconheceu as unióes estáveis homossexuais como entidades familiares, o que dentre outras conseqüências facilitou a adoção homoparental ${ }^{3}$ por casais. O objetivo da nossa pesquisa de mestrado, da qual o presente trabalho é um resultado preliminar, é entender as representaçôes da homossexualidade a partir dos discursos jurídicos sobre adoção na comarca do Rio de Janeiro que, inclusive, an- 
A REPRESENTAÇÃo DA HOMOSSEXUALIDADE NOS DISCURSOS JURÍdICOS $\mid 25$ I

tes da referida decisão do STF já permitia a adoção por casais homossexuais.

$\mathrm{O}$ que apreendemos até agora do universo de nossa pesquisa leva-nos a supor que há uma positivação da adoção por casais homossexuais, sustentada por um discurso de garantias de direitos a estes cidadãos, que se baseia no princípio constitucional da dignidade humana, frente a um contexto social de muita polêmica quando se trata da parentalidade exercida por homossexuais. Que marcaçóes estão presentes à homossexualidade no discurso jurídico dos processos de adoção a partir de tal situação?

Minha pesquisa de campo consiste na análise de processos de habilitação e adoção ${ }^{4}$ majoritariamente de casais homossexuais, mas também de alguns solteiros e de casais heterossexuais, de duas varas da infância, da juventude e do idoso da comarca da capital do Rio de Janeiro. Além disso, venho realizando entrevistas com as equipes técnicas, psicólogos e assistentes sociais, coordenadores de grupos de apoio à adoção, pretendentes à adoção e pais e mães adotivos. A participação em congressos e encontros na área do direito de família sobre o tema em questáo tem me servido não só de campo, como me dado as bases doutrinárias do direito à respeito da questão.

\section{Família, Parentesco e Homossexualidade}

O reconhecimento estatal das uniôes homossexuais como "família" é bastante polêmico. A questão que se coloca é se a família pode ser vivenciada, de modo adequado, a partir da parentalidade homossexual. Isto porque haveria um papel simbólico fundamental atribuído a cada gênero no desenvolvimento da personalidade infantil que, de acordo com aqueles que são contra a homoparentalidade, seria impossí- vel de ser desempenhado pelo par homossexual, onde a diferença sexual não se faz presente no arranjo parental.

A importância dos papéis de gênero, na teoria freudiana clássica, se percebe, sobretudo por meio do chamado "Complexo de Édipo". Meninos e meninas passariam por um estágio inicial em seu desenvolvimento tomando ambos por objeto da libido a figura da mãe. A partir daí, em processos diferenciados - dentre os quais a psicanálise clássica deu muito mais atenção para o dos meninos - ocorreria o corte do desejo libidinal em relação à mãe, graças à figura do pai, a identificação progressiva do menino com o pai, pelo medo da castração que esse lhe inspira, a escolha do pai pela menina como objeto amoroso e a identificação dessa com a mãe (STOLLER, 1993).

A homoparentalidade, interpretada a partir de uma visão clássica sobre a importância das funçôes parentais para o desenvolvimento da personalidade, se constitui numa grande ameaça, não só ao sadio desenvolvimento infantil, mas, segundo os seus opositores mais ferrenhos, à própria sociedade, à medida que ameaça suprimir a diferença sexual, elemento necessário e constitutivo da "cultura" (ROUDINESCO, 2003).

A forma mais comum de resolver a questão das funçóes parentais no caso da homoparentalidade, como se verá na análise das entrevistas e dos processos que compóem a pesquisa, é a substituição no exercício das funções parentais do pai e da mãe por outras pessoas próximas ao casal homossexual que garantam assim a "ordem simbólica" pela conservação da diferença sexual; saída que parece deixar intocada a principal questão: Será que o desenvolvimento da personalidade, a entrada da criança no mundo social, tem como base necessária a relação binária dos gêneros, senão presente nos pais, pelo menos no convívio desses com uma 
espécie de "substituto de gênero oposto" ao do casal homossexual?

Elizabeth Zambrano, psicanalista e antropóloga, em comunicação oral, durante o painel "A filiação no direito homoafetivo" do III Congresso de Direito Homoafetivo, da Ordem dos Advogados do Brasil, realizado no ano de 2013, defende que os papéis atribuídos tradicionalmente aos pais são papéis de "cuidadores", "pai" e "mãe" são apenas os casos mais comuns de cuidadores. Segundo a autora (2006) a função paterna enquanto promotora da separação psíquica entre mãe e filho, atribuição clássica da psicanálise, pode ser compreendida como a necessidade da entrada de um "terceiro" na relação, não necessariamente alguém do sexo oposto ao da mãe: "Tanto nos casais gays quanto lésbicos, a função de "terceiro" pode ser exercida pelo parceiro/a do pai/mãe" (ZAMBRANO, 2006, p. 24). Para a criança, o importante seria a descoberta de um(a) "outro(a)" para o qual se orienta o desejo do(a) pai/mãe. Assim, as marcaçóes específicas de gênero nas funções parentais não só não precisariam estar ligadas aos pais especificamente, como, de fato, não precisariam existir enquanto necessidade só satisfeita pela binariedade de gênero.

Repensando de modo radical os pressupostos estruturalistas da psicanálise ou reinterpretando-os de modo a incluir a homoparentalidade no rol da "normalidade", o fato é que a psicanálise tornou-se um campo de imenso prestígio no debate sobre a questão, uma espécie de "guardiã das boas condições de subjetivação” (TORT, 1999, apud PERELSON, 2006, p. 713), muitas vezes, calcando essas boas condiçóes na heterossexualidade dos pais. Tratando a respeito do "Complexo de Édipo”, Roudinesco (2003) afirma que ele se tornou o dogma de uma espécie de conservadorismo muito adaptado ao modelo de família do início do século XX, mas pouco capaz de dar conta dos novos arranjos familiares e da nova realidade da relação entre os gêneros.

Supóe-se que a parentalidade homossexual, por si só, independente das características pessoais dos indivíduos que as exerçam, seria suficiente para prejudicar o equilíbrio psíquico dos filhos, por causa do "narcisismo patológico do homossexual", da "negação da diferença dos sexos" e do "caráter arcaico e desviante da sexualidade homossexual", algumas das razóes levantadas pelos opositores ao projeto de lei sobre a parceria civil de homossexuais na França, elencadas por Simone Perelson (2006, p. 713).

Segundo Erving Goffman (1978), uma das consequências do estigma é que a característica estigmatizada do indivíduo se impóe às demais, destruindo a possibilidade de atenção para outros atributos que o indivíduo estigmatizado possui. Isso normalmente ocorre deduzindo-se a partir da característica estigmatizada, uma série de outras que denigrem o perfil moral do indivíduo em questão, por exemplo, quando se associa a homossexualidade masculina à promiscuidade de forma automática ou assumindo - como visto acima - que por si só, a homossexualidade se opóe à parentalidade.

Se, a partir de uma perspectiva que reputamos como mais tradicional, o casal homossexual aparece distante do modelo familiar, visto ser este perpassado pelos papéis de gênero que tem sua realização mais esperada na reprodução; as características dos chamados "novos arranjos familiares" flexibilizam os parâmetros familiares tradicionais, possibilitando o reconhecimento das unióes homossexuais como entidades familiares. Isso porque em tais arranjos a razão de ser do casamento aparece como puramente afetiva, as unióes são pautadas, pelo menos idealmente, no igualitarismo entre os/as parceiros e não há a obrigação de uma sexualidade reprodutiva (HEILBORN, 2004). 
A REPRESENTAÇÃo DA HOMOSSEXUALIDADE NOS DISCURSOS JURÍDICOS $\mid 253$

Por outro lado, há de se supor que, se as fronteiras familiares encontram-se mais abertas para os casais homossexuais que desejarem assumir tal configuração de vida, e sendo a família, ainda hoje, fortemente permeada pela questão dos filhos, entende-se que a homoparentalidade desponte como questão atualíssima. Uma das formas que esses casais homossexuais buscam para realizar seu desejo parental é a adoção.

\section{As transformaçóes doutrinárias da família no cenário jurídico nacional e o impacto na questáo da adoçáo.}

A Constituição Federal de 1988 consagrou importantes transformações na compreensão que se tinha, no direito, a respeito da noção de família e de seu papel. O laço familiar deixa de ser entendido como um contrato civil com fins de garantir a transmissão de patrimônio. $\mathrm{O}$ que passa a caracterizar essencialmente as relaçôes familiares é a substituição da ideia de "negócio legítimo" pela de "comunhão plena de vida” (ZARIAS, 2008, p. 95). A função da família passa a ser encarada no direito como instrumental, ela visa ao desenvolvimento pessoal de seus membros. Doutrinalmente, essa nova concepção de família consagrada pela Constituição Federal de 1988 passou a ser denominada de "Família eudaimonista", porque está voltada para a realização personalística de seus membros (TORRES, 2009).

Essa mudança de perspectiva no direito de família pode ser interpretada como reflexo das transformaçôes sofridas pelos arranjos familiares nas últimas décadas. Apesar da pluralidade de elementos que compóem esses novos arranjos familiares, podemos citar a importância da satisfação afetiva para a manutenção do vínculo conjugal que não se fundamenta, como até entâo, em base institucional, mas num proje- to comum que tem por alicerce a vontade de estar junto, ou seja, o casamento náo tanto como instituição, mas como relação (PAIVA, 2007). A família entendida como lugar da realização de seus membros passa a ser entendida como se constituindo não fundamentalmente a partir dos laços biológicos, e sim dos afetivos: 5 "O prestígio da afetividade fez surgir uma nova figura jurídica, a filiação socioafetiva, que acabou se sobrepondo à realidade biológica" (DIAS, 2007, p. 107).

O paradigma do afeto para a definição do laço familiar no mundo jurídico impacta a adoção no sentido em que esta era, muitas vezes, vista como uma substituta à filiação biológica, permanecendo à sombra desta. Com o afeto elevado a valor central, e sendo este o único elo constitutivo na filiação adotiva, haveria, segundo relatos do campo, uma nova postura com relação à adoção, marcada pelo orgulho e não pela vergonha em relação a este tipo de filiação. ${ }^{6}$

Outra consequência dessa mudança no direito de família, como visto, foi a possibilidade de reconhecer as uniôes homossexuais como entidades familiares. Nesse contexto, é interessante que, no campo do direito, a nomenclatura para se referir às relaçóes homossexuais e, em alguns casos, à própria homossexualidade, seja a de "homoafetividade" (VECCHIATTI, 2013). Tal termo quer aproximar de forma menos conflituosa as uniōes homossexuais do estatuto de "família", nomeando-as a partir do "afeto", que como visto, se constitui, no valor fundamental para se configurar o que seja a família, a partir de 1988.

Goffman (1978) afirma que os grupos estigmatizados adotam algumas estratégias para repropor a identidade social deteriorada de uma forma mais positiva. A primeira delas seria a adoção de uma nomenclatura não contaminada pelo preconceito, o que no caso da 
homossexualidade, se realizou pela adoção do termo "gay", primeira forma de classificação auto-denominada e que sendo um adjetivo cujo significado é "alegre", demonstra a postura de orgulho perante a condição homossexual. Nesse sentido, no âmbito do direito, o uso do termo "homoafetividade" realçaria os aspectos tidos como "positivos" da homossexualidade, capazes de mostrá-la plenamente adequada à parentalidade.

Haveria uma "preocupação com a purificação intragrupal” (GOFFMAN, 1978, p. 93) que procura "descrever os esforços de pessoas estigmatizadas não só para 'normificar' o seu próprio grupo, mas também para limpar totalmente a conduta de outras pessoas do grupo" (GOFFMAN, 1978, p. 93) o que, no caso da adoção por homossexuais, se expressaria numa necessidade de reproduzir a própria vivência conjugal e parental nos moldes heterossexuais de família e numa preocupação que se expressa no "não poder falhar" (GARCIA et al., 2007).

\section{Análise dos dados preliminares do campo}

Ouve-se constantemente no campo a ideia de que há uma "nova cultura da adoção", que corresponderia a uma atitude de orgulho diante da filiação adotiva. Nesse sentido do orgulho a respeito da adoção, é interessante registrar que uma das formas de se manifestar isso publicamente, tem sido a realização de uma caminhada na orla de Copacabana, no dia nacional da adoção, 25 de maio, realizada pela "militância" em prol da adoção, com a presença de diversos setores envolvidos na questáo: operadores do direito que agem no processo, grupos de apoio à adoção, pais e filhos por via da adoção, todos com cartazes, camisetas, gritando palavras de ordem, uma verdadeira manifestaçáo.

A adoção também tava no armário. As pessoas náo diziam que adotavam, nem quem era adotado se assumia como adotado. (...) Acho que nas adoçóes antigas, a família não assumia a adoção. (...) E hoje não. Hoje a adoção saiu do armário, as pessoas se assumem como pais adotantes. Quem foi adotado se assume como adotado. Nós tivemos uma alteração de concepção da adoção muito grande também. Não é vergonha para ninguém ser adotado, muito pelo contrário. (Aline, coordenadora de grupo de apoio à adoção) $)^{7}$

Essa publicização da adoção como valor se inscreve, inclusive, como critério para avaliação dos candidatos à adoção. A disponibilidade destes em contar para as crianças a forma de filiação que constituiu a família, é tida pela equipe técnica como algo relevante, pois fazer da adoção um segredo poderia ser um "complicador até na própria construção da personalidade dessa criança” (Berta, membro de equipe técnica).

A importância do afeto, base fundamental da adoção, aparece no campo através da afirmação recorrente entre os entrevistados de que, mesmo na filiação biológica, alguém só pode ser bom pai ou mãe se também "adotar" seu filho, ou seja, se mais do que um fato biológico, a parentalidade for assumida como um projeto pessoal. Postura essa que, talvez, expresse o desejo de combater certa desconfiança social a respeito da adoção, pela centralidade do paradigma biológico da filiação em nossa sociedade, mostrando que a filiação biológica também é perpassada pela necessidade do "acolhimento afetivo" da criança, presente na filiação adotiva.

$\mathrm{Na}$ decisão do STF (2011), que reconheceu as unióes homossexuais como entidades 
A REPRESENTAÇÃO DA HOMOSSEXUALIDADE NOS DISCURSOS JURÍDICOS $\mid 255$

familiares, há uma concepção que entende a garantia progressiva de direitos a tipos de uniáo outrora excluídos da categoria de "família": primeiro às uniôes estáveis heterossexuais, a partir da Constituição Federal de 1988, e, então, às homossexuais. Essa concepção de uma garantia progressiva de direitos que se estende às unióes homossexuais produz um efeito nos discursos dos envolvidos no processo de adoçẫo, apreendido nas entrevistas. Tende-se a minimizar os conflitos em relação ao reconhecimento das uniôes homossexuais como família e da adoção homoparental, quase como se a decisão jurídica que as possibilitou produzisse uma conversão automática de mentalidades, como se a questáo, resolvida no âmbito do judiciário, resolvesse também as controvérsias sociais sobre o tema. Uma entrevistada, atuante nos processos de adoção, diz que se está "numa outra fase da evolução da sociedade, onde as famílias são respeitadas por ser um núcleo de cuidado, de carinho e não pela sua configuração heterossexual", essa questão "já acabou há muitos anos" e seria preciso "passar esse nível” (Carla).

O reconhecimento dos direitos sexuais como direitos humanos no âmbito judiciário impóe certa coerção aos discursos sobre a adoção homoparental, bastante expressiva nas entrevistas. Um membro da equipe técnica de uma vara da infância, após utilizar o termo "homossexualismo", pede, com bastante insistência, que eu o exclua, já que o sufixo "ismo" está associado à doença e conclui: "A gente tem que se policiar tanto com as palavras... exatamente pra não parecer: 'Olha, estou discriminando"'. Minha interpretação desse fato não é a de que houvesse algum preconceito "encoberto" na fala em questáo, entretanto, o episódio revela uma precaução que está constantemente presente nos discursos, a de que a fala concorde com a regra estabelecida, uma espécie de "auto-patrulhamento politicamente correto” não só no que se diz, mas até no como se faz.

Até agora, realizei doze entrevistas, sendo quatro com psicólogos e assistentes sociais que compóem as equipes técnicas das varas de infância e juventude, quatro com coordenadores de grupo de apoio à adoção, duas com pais ou mães adotivos e duas com pretendentes a adoção. Percebe-se, especialmente no discurso das equipes técnicas nas entrevistas, certa resistência emblemática sobre o tema das especificidades da adoção homoparental.

Minha hipótese é que as resistências em reconhecer as especificidades da adoção homoparental diante do estado da questão na sociedade atual pode ser interpretada como um "desidentificador", conceito de Goffman (1978, p. 40), que compreende um ator social que serve para quebrar a coerência esperada entre estigma e performance social, no caso, mostrar que os homossexuais são aptos a serem pais.

A minha posição de pesquisador e o tema da pesquisa, adoção homoparental, colaboram para esse "auto-patrulhamento", fornecendo o contexto de produção do discurso dos entrevistados, regulamentando tal discurso a partir dos valores que são trazidos à tona pelo tema em questão; deste modo, organizam-se estratégias que permitem a circulação de certos enunciados na fala dos entrevistados, interditando-se outros (INIGUEZ, 2004), como afirma Foucault: "A produção do discurso é simultaneamente controlada, selecionada, organizada e redistribuída por um certo número de procedimentos que têm por papel exorcizar-lhe os poderes e os perigos" (FOUCAULT, 2007, p. 2)

Berta, membro de equipe técnica, afirma que eu não encontrarei, explicitamente, nenhuma objeção à adoção homoparental por parte de psicólogos das varas de infância. Admite, no entanto, que os discursos das equipes técnicas podem não corresponder à convicção pessoal dos profissionais que compóem essas equipes, o 
que poderia vir a aparecer, de uma forma ou de outra, no laudo técnico que faz parte do processo, já que, como alega, "não há objetividade sem parêntesis, só com parêntesis", por isso, o laudo se faz a partir do que se "vê" e esse recorte pode ser "extremamente tendencioso", afinal, conclui: "atrás do processo, tem gente".

Com relação às funções parentais, que baseadas na divisão de sexos, são muitas vezes utilizadas como argumento contrário à homoparentalidade, o que tem aparecido, nas entrevistas até agora realizadas, é que os homossexuais não prejudicam em nada o desenvolvimento de seus filhos porque seriam, a despeito de sua orientação sexual, plenamente capazes de fazê-los vivenciar a questão da "diferença sexual".

Não são, necessariamente, um pai e uma mãe que irão mostrar os códigos sociais do "masculino" e do "feminino" à criança, segundo Gustavo, membro da equipe técnica de uma vara de infância. Numa entrevista com um casal de lésbicas que estão em processo de adoção, uma das mulheres esclarece que acha importante a referência masculina e feminina para a criança, mas que estas não precisam vir necessariamente do casal. O convívio social proporcionado pelos amigos, pela escola, pelos parentes homens das duas é tido como suficiente para cumprir essa função.

As funções "paterna" e "materna" mantêm importância no discurso dos entrevistados, não assumindo tal função simbólica, na imensa maioria dos discursos, a feição mais geral de "função de cuidador", como proposto por Elizabeth Zambrano, no congresso anteriormente citado. O que se propóe nos discursos é a desvinculação dessas funções do exercício necessário dos pais, ademais impossível no caso de casais homossexuais, pela não diferenciação sexual. Assim, uma criança filha de duas mulheres pode contar com a "figura paterna" através da convivência com os amigos e com os parentes homens do casal, do mesmo modo que uma criança filha de dois homens contará com as avós, madrinha e amigas do casal.

Flexibiliza-se o ator que exercerá as funções, mas não a ligação dessas com a binariedade dos gêneros, quase como se o cumprimento de tais funçóes se desse nesses casos, assim como em outros onde não existe na parentalidade a divisão sexual - mães solteiras, por exemplo, por uma espécie de suplência em relaçẫo ao modelo único que garantiria de antemão, sem necessidade de justificaçóes, as exigências psíquicas das funções parentais, aquele na qual a parentalidade é vivida a partir da diferença sexual, o da família nuclear composta por pai, mãe e filho.

\section{Estratégias discursivas em relaçáo à homoparentalidade: $\mathrm{A}$ "invisibilização" e a "positivação"}

O efeito de "abrandamento" das controvérsias sociais nos discursos dos envolvidos no universo da adoção, que a posição do judiciário sobre a adoção homoparental produz, se dá, até onde nossa pesquisa de campo já nos permite induzir, a partir de duas estratégias, na forma como a orientação sexual dos candidatos à adoção é tratada: a invisibilização das peculiaridades da adoção por casais ou pretendentes homossexuais ${ }^{8}$ em comparação com a adoção por heterossexuais - peculiaridades que se evidenciam pelo estatuto polêmico da homossexualidade, ainda hoje, em nossa sociedade - e uma espécie de "positivação" da homossexualidade presente em tais discursos.

O que estou chamando de "invisibilização das peculiaridades" parece corresponder à uma lógica, segundo a qual, reconhecer as peculiaridades presentes na questão da homoparentalidade equivaleria a reforçar os preconceitos 
históricos aos quais o tema está ligado. Esta lógica aparece de forma muitas vezes sutil durante as entrevistas, numa resistência em reconhecer que a própria homoparentalidade, pelo seu estatuto social controverso, permeado de aceitaçóes, mas também das mais diversas condenaçôes, produz um efeito sobre os candidatos homossexuais que se apresentam à adoção, sem falar nos operadores do próprio direito e demais envolvidos no processo. O que se percebe, muitas vezes, é a crença de que ao acessar o papel profissional, o indivíduo neutralizaria suas tantas outras dimensóes e pertenças no mundo, para além da exercida no judiciário.

A lógica da "invisibilização" também perpassa a própria questão da adoção, como forma de filiação alternativa à biológica. Percebe-se nas entrevistas, especialmente com pais heterossexuais, a preocupação de que reconhecer as especificidades dessa forma de filiação seria já desvalorizar, de algum modo, a adoção. Falando sobre uma questão com a filha mais nova, Aline, para especificar de qual filha se tratava, já que possui outra filha por via biológica, me diz que se trata da "filha adotada" e imediatamente emenda "a gente náo faz essa diferença porque filho é filho e acabou”. Em outra entrevista, assim que Dênis, o marido, classifica uma reação à discriminação de uma escola quanto ao filho adotado de uma conhecida como "de mãe adotiva" é interrompido, na mesma hora por Flávia, sua esposa, que o corrige: "Não de mãe adotiva, de mãe"?

\section{Heterossexuais e Homossexuais em questáo}

Pode-se postular, por exemplo, nas entrevistas, que um casal homossexual chegue à vara de infância com uma "carga" muito menor de sofrimento do que a de um casal heterossexual, em relação ao projeto de paternidade desejado por eles. Isso porque é muito comum que os casais heterossexuais, pelo menos aqueles que têm condiçóes financeiras para tal, optem pela adoção após tentarem gerar um filho através das tecnologias reprodutivas, como diz Berta, após "muitos anos de investimento financeiro e emocional nesses tratamentos pra fertilidade".

Carla, advogada atuante nos processos, entende, ao contrário de Berta, que, sendo a decisão de ter um filho ainda cheia de dificuldades sociais para casais homossexuais, aqueles que chegam a tomá-la possuem um casamento bastante sólido, "são casamentos muito bem firmados porque não é uma decisão fácil”. Nesse sentido, a própria homossexualidade aparece como fator de amadurecimento pessoal, pelas dificuldades apresentadas em relação tanto à orientação sexual quanto à formação de uma família em tais moldes, e a decisão de adotar como que coroa esse processo, servindo como uma espécie de atestado dessa maturidade do casal. De acordo com essa lógica, o próprio preconceito social favoreceria, de algum modo, a estabilidade do vínculo conjugal nos casais homossexuais, pelo fato de terem de lutar mais para reafirmar sua opçáo de vida e seu modelo familiar.

A estratégia de positivação da homossexualidade que a transforma, por si só, numa "vantagem adotiva” para os candidatos em questão, pela compreensão de que seu próprio histórico de vida os torna mais maduros e sensíveis, obedece à mesma operação lógica que, muitas vezes, tem como resultado a desqualificação do indivíduo homossexual. A lógica operante nos dois casos, ainda que de resultados opostos, é a do encobrimento das outras características do indivíduo pela presença de um predicado específico que lhe marcaria definitivamente o caráter moral, enaltecendo-o, no caso da positivação e o denegrindo, na desqualificação. 
Outra ocorrência da lógica estigmatizante que associa imediatamente o estigma à outros predicados desabonadores, independente da real presença destes no sujeito estigmatizado, é a associação frequente nas entrevistas entre masculinidade e certo perigo de abuso sexual. A raiz de tal ligação parece ser a atribuição de uma "hipersexualização" ao gênero masculino que sempre gozou na sociedade ocidental de maior liberdade sexual. Tal associação é tematizada por Berta quando afirma que as pessoas, em geral, não veem nenhum problema numa adoção monoparental por parte de uma mulher, outra forma de associação imediata, entre "feminino" e "maternidade", mas quando o candidato à adoção monoparental é um homem, pensam: "Ah, então só pode ser homossexual, será que não vai abusar da criança?", atribuindo-se assim, em alguns discursos, ao homem gay uma acentuação ainda maior da "hipersexualização" associada ao gênero masculino.

Em outra entrevista, Marta, coordenadora de grupo de apoio à adoção, afirma que fica muito mais tranquila quando vê um casal gay adotar uma criança do que um homem heterossexual solteiro "por causa da pedofilia", justificando que "o gay, o homem que escolhe um outro homem pra parceiro, nossa, eles são de um respeito com aquela criança...”.

É interessante perceber que a associação entre masculinidade e abuso ganha inflexôes diferentes na intersecção do gênero com o "estado civil" do candidato. O homem solteiro é tido como potencialmente mais perigoso, ${ }^{10}$ o que em contrapartida, mostra como a conjugalidade tem como consequência um acréscimo na respeitabilidade, na forma como a idoneidade moral do candidato homem é percebida, isso parece ser ainda mais verdadeiro no caso dos homens gays, ${ }^{11}$ pelo próprio estigma ligado à homossexualidade.

$\mathrm{Na}$ análise dos processos, não aparece a invisibilidade das peculiaridades que a adoção homoparental acarreta num contexto como o atual. Talvez porque não haja um interlocutor obstinado em saber, justamente, sobre essas peculiaridades, como no caso das entrevistas. Nos processos analisados até aqui, percebe-se que a orientação homossexual do(s) adotante(s) é sempre algo a ser considerado. Náo que seja um impedimento, mas se póe como especificidade que exige que se detenha nela, inclusive para se justificar porque não é um impedimento, o que, por si só, já marca uma diferença em relação aos processos cujos adotantes são heterossexuais, nos quais a questáo da sexualidade nem aparece. Assim, por exemplo, é preciso justificar que apesar da "lacuna da lei em dispor sobre tal possibilidade" (processo 1) pelo que é preciso aplicar "as fontes secundárias do direito (analogia, costumes e princípios gerais)" e ressaltar que "o art. 1622 do CC não veda a adoção por casal homossexual" (processo 1); da mesma forma, é preciso explicitar que a "habilitação dos postulantes vem abrigada no principio da igualdade e da não discriminação" (processo 2).

Além dessa logística de argumentação legal que se desenvolve pelo simples fato do requerente ser homossexual, há outras questóes que se fazem necessárias especificamente nesse caso da adoção homoparental. Em um processo de habilitação, numa comarca do Paraná, de um casal homossexual, cujo posterior processo de adoção foi realizado no Rio de Janeiro, lê-se, no estudo psicossocial, que "estão juntos porque um tem carinho pelo outro e a relação não é baseada apenas no sexo" (processo 2), fruto da concepção social que tende a enxergar a homossexualidade masculina como promíscua, de relaçóes efêmeras, incapaz de laços mais estáveis. Não se encontra afirmação semelhante em nenhum laudo psicossocial em processo de casais heterossexuais.

Assim como nas entrevistas, também nos processos analisados até o presente momento da pesquisa a questão sobre as "funçôes 
A REPRESENTAÇÃo DA HOMOSSEXUALIDADE NOS DISCURSOS JURÍDICOS 259

parentais", ou seja, o papel específico que "pai" e "mãe" desempenhariam no desenvolvimento da psiché infantil, não surge como um problema que impeça a adoção homoparental. Em um processo de habilitação de um casal homossexual masculino, após afirmar que tanto a função paterna, entendida como "proteção, limite e direção", quanto a materna, concebida como "provendo o vínculo, a nutrição e a organização", precisam existir para garantir à criança sua estrutura psíquica, diz o laudo que tais funçóes serão supridas pelo "equilíbrio do casal (...) junto com a ajuda da madrinha e dos amigos que os cercam" (processo 1).

A "positivação" da conjugalidade homossexual também aparece no campo a partir das falas dos operadores do direito presentes nos congressos. Na palestra "Relações familiares e Homoafetividade", durante o III Congresso de Direito Homoafetivo, realizado na cidade de Vitória, no Espírito Santo, em maio de 2013, o titular do Núcleo Especializado de Promoção e Defesa dos Direitos Individuais e Coletivos da Mulher da comarca de Vitória e da Defensoria Pública do Estado do Espírito Santo, afirmou em relação às denúncias motivadas pela Lei Maria da Penha (lei no 11.340, de 7 de agosto de 2006) que, em sete anos de vigência da lei, atendeu 36.000 mulheres vítimas de violência masculina e nenhuma mulher agredida por companheira. Baseado em tal dado, afirma que os casais homossexuais são diferentes dos heterossexuais, pelo menos os femininos contemplados pela referida lei, pois "desconhecem a violência (...) O elemento 'violência' é algo estranho às relações homossexuais", assim "os homossexuais são diferentes de nós, os heterossexuais, que sabemos ser violentos".

Nega-se assim a existência de violência em casais lésbicos, o que parece se dar pela atribui- ção de um caráter menos violento às mulheres do que aos homens. Interessante no debate que se seguiu à tal colocação foi a fala de uma participante, auto-identificada como "militante lésbica”, afirmando que haveria sim muita violência em casais homossexuais femininos, o que não ocorreria seria a denúncia de tal situação, por desconhecimento da lei ou vergonha diante do Estado.

\section{Consideraçóes finais}

A partir dos dados preliminares da pesquisa acima expostos, entendo que o tom, muitas vezes, normatizador do discurso das equipes técnicas sobre a adoção homoparental, não constitui simples expressão de uma situação resolvida, como muitas vezes parece ser proposto pelas entrevistas, mas um meio de assegurar que se resolva, ou seja, encaro o discurso que parece abrandar a questão, negando o conflito, como uma posição específica nesse mesmo conflito. Posição essa que também explica a "positivação" da homossexualidade nos discursos a fim de mostrá-la apta ao projeto parental desejado pelos candidatos homossexuais à adoção.

O perigo que espreita a tal postura é a consagração de uma homossexualidade conjugal que se transforme em modelo e, no âmbito do direito, que se torne quase sinônimo da própria homossexualidade, lançando outras experiências homossexuais ainda mais para a margem (BUTLER, 2002) e impondo a obrigação de "dar certo" para os casais adotantes, como expressa a fala de Nair, mãe adotiva em união estável homossexual, que afirma que há um aumento na responsabilidade na criação das crianças e na manutenção da união porque é preciso "dar ainda mais exemplo", já que as adotantes são um casal de lésbicas. 


\section{Notas}

1. Mestrando em Ciências Sociais no Programa de PósGraduação em Ciências Sociais (PPGCS) da Universidade Federal Rural do Rio de Janeiro (UFRRJ).

2. Das três varas da infância e da juventude da capital, realizamos pesquisas nas varas regionais de Madureira e Santa Cruz. A $1^{\circ}$ Vara da Infância e Juventude, até o presente momento, não deu qualquer resposta ao meu pedido de pesquisa.

3. O termo "homoparentalidade" é tradução do francês homoparentalité, cunhado em 1997, pela Association des parents et futurs parents gays et lesbiens (APGL) (UZIEL, 2007).

4. O processo de habilitação do candidato é o que atesta, caso seja deferida a habilitação, que este se encontra em condiçôes para adotar uma criança ou adolescente. O processo de adoçáo é o que terá como resultado a filiação de uma, ou mais, criança(s) ou adolescente(s) por meio do vínculo jurídico estabelecido pela decisão do juiz. Em ambos os processos a atuação da equipe técnica das Varas de Infância, da Juventude e do Idoso, é fundamental. Outro ator importante no processo são os Grupos de Apoio à Adoção. $\mathrm{O}$ candidato à habilitação na comarca do Rio de Janeiro é obrigado a participar de um número determinado de reunióes. Tais grupos funcionam tanto para o esclarecimento do processo quanto como uma rede de apoio e solidariedade aos candidatos à habilitação, aos já habilitados e, algumas vezes, aos pais adotivos através da partilha de suas vivências.

5. Ainda que o paradigma biológico se reafirme como definidor essencial dos laços familiares em outras instâncias no universo jurídico, por exemplo, na importância contemporânea do "exame de DNA" nos processos de reconhecimento de paternidade (FONSECA, 2004)

6. É importante compreender essa "novas postura de orgulho” em relação à filiação adotiva, afirmada, sobretudo, nas entrevistas com as equipes técnicas e com aqueles que podemos chamar de "militantes" da causa da adoção, por exemplo, coordenadores de Grupos de Apoio à Adoção (GAA), como um valor a ser promovido ao longo das várias etapas do processo de adoção já que muitos candidatos a pais e mães adotivos ainda procuram essa forma de filiação após várias tentativas frustradas de gerar filhos biológicos.

7. Os nomes dos entrevistados são fictícios.
8. Como a orientação sexual não é critério para se habilitar à adoção, a homossexualidade não aparece necessariamente nos processos de adoção monoparental, assim é no caso da adoção por casais homossexuais que a questão mais se evidencia no processo.

9. Apesar do objeto da minha pesquisa ser a adoçáo homoparental, tive acesso à entrevistas e cheguei a realizar algumas com pais adotivos heterossexuais, graças ao projeto "Adoção em seus múltiplos sentidos" coordenado pela minha orientadora, Profa. Alessandra Rinaldi.

10. O mesmo dado aparece na pesquisa de Ana Paula Uziel sobre adoção e homossexualidade: "Apesar de a pessoa sozinha, independente do sexo, despertar questionamentos próprios à tal condição, o homem que assim se apresenta gera mais inquietaçôes" (UZIEL, 2007, p. 29).

11. Em um texto clássico, Rubin propóe a existência de níveis de "respeitabilidade erótica" demarcados fundamentalmente por uma linha divisória entre a ordem e o caos sexual. Em decorrência das mudanças nas formas de viver a sexualidade, experimentadas, sobretudo, a partir das décadas de sessenta e setenta, alguns comportamentos estariam ultrapassando a linha, migrando para a "respeitabilidade erótica". Seria o caso, dentre outros, de certas vivências homossexuais. Mesmo reconhecendo que "boa parte da homossexualidade continua no lado mau da linha" (RUBIN, 2003, p. 16), se a vivência homossexual for "em casal e monogâmica, a sociedade está começando a reconhecer que ela inclui uma gama completa de interação humana." (ibidem).

\section{Lista dos processos}

Processo 1 - Processo 0319.583.412010-8

Processo 2 - Processo 2005.000.797900-0

\section{Referências bibliográficas}

BUTLER, Judith. Is Kinship Always Already Heterosexual? In: Indifferences: A journal of feminist cultural studies, v. 13, n. 1, p. 14-45. 2002.

DIAS, Maria Berenice. Família e sucessôes. In: Revista do advogado, ano 27, maio, n. 91, 2007. 
A REPRESENTAÇÃo DA HOMOSSEXUALIDADE NOS DISCURSOS JURÍDICOS $\mid 26$ I

FONSECA, Claudia. A certeza que pariu a dúvida: paternidade e DNA. In: Revista Estudos Feministas, vol.12, n. 2, ago, p.13-34. 2004.

FOUCAULT, Michel. A ordem do discurso. $15^{\circ} \mathrm{Ed}$. São Paulo: Loyola. 2007.

GOFFMAN, Erving. Estigma: notas sobre a manipulaçáo da identidade deteriorada. Rio de Janeiro: Zahar. 1978.

HEILBORN, Maria Luiza. Dois é par: Gênero e identidade sexual em contexto igualitário. Rio de Janeiro: Garamond. 2004.

PAIVA, Antonio. Reservados e invisiveis: o ethos íntimo das parcerias homoeróticas. Campinas: Pontes. 2007.

PERELSON, Simone. A parentalidade homossexual: Uma exposição do debate psicanalítico no cenário francês atual. In: Estudos Feministas, Florianópolis, N. 14(3), set-dez, p. 709-730. 2006.

ROUDINESCO, Elizabeth. A familia em desordem. Rio de Janeiro: Jorge Zahar. 2003.

RUBIN, Gayle. Pensando o sexo: Notas para uma teoria radical das politicas da sexualidade. 2003. Disponível em: <http://www.miriamgrossi.cfh.prof.ufsc.br/pdf/ gaylerubin.pdf>. Acesso em: 6 dez. 2012.
STOLLER, Robert. Masculinidade e Feminilidade: Apresentaçôes de gênero. Porto Alegre: Artes médicas. 1993.

SUPREMO TRIBUNAL FEDERAL. ADI 4.277/ DF. Relator: Min. Ayres Britto. Julgamento em: 05/05/2011, publicado no DJ de 14-10-2011 p. 2607-3. Disponível em: <http://www.stf.jus.br/portal/autenticacao/>. Acesso: 1 abr. 2013.

UZIEL, Ana Paula. Homossexualidade e Adoção. Rio de Janeiro: Garamond. 2007.

VECCHIATTI, Paulo Roberto Iotti. Manual da Homoafetividade: Da possibilidade jurídica do casamento civil, da união estável e da adoção por casais homoafetivos. São Paulo: Ed. Método ltda. 2013.

ZAMBRANO, Elizabeth. et al. $O$ direito à homoparentalidade: Cartilha sobre as familias constituidas por pais homossexuais. Porto Alegre: Vênus. 2006.

ZARIAS, Alexandre. Das leis ao avesso: Desigualdade social, direito de família e intervenção judicial. Tese (Doutorado em Sociologia) - Faculdade de Filosofia, Letras e Ciências Humanas, Universidade de São Paulo, São Paulo. 2008.

$\begin{array}{ll}\text { autor } & \text { Rafael Morello Fernandes } \\ \text { Mestrando em Ciências Sociais / UFRRJ }\end{array}$

Recebida em 08/11/2013

Aceita para publicação em 16/12/2013 